\title{
The Influence of Parents' Parenting Style towards the Independence of Preschool Children
}

\author{
Lydia Margaretha', Nina Kurniah', I. Wayan Dharmayana', Rambat Nur Sasongko' and M. Lutfi \\ Firdaus $^{2^{*}}$ \\ 'Magister of Education Administration, University of Bengkulu, Indonesia; lydiamargaretha79@yahoo.com, \\ nina_kurniah@yahoo.com, iwayand386@gmail.com, rambatnur@yahoo.com \\ ${ }^{2}$ Graduate School of Science Education, University of Bengkulu, Indonesia; lutfi@unib.ac.id
}

\begin{abstract}
Objectives: To find out parenting style implemented by parents of preschool children and the influence of parenting style of parents toward independence. Methods/Statistical Analysis: The research method applied was quantitative approach. The population in this research was as many as 260 students. The number of samples determined based on cluster random sampling technique was 90 students. The data collection technique was conducted by doing validity testing, reliability, instrument, normality test, linearity test and hypothesis test which are processed by using SPSS 16.0 for windows program. Findings: The research findings show that most of the parents of preschool children at Ratu Agung District of Bengkulu City implemented democratic parenting style. The percentages of independence level of preschool children were as follow: $16.67 \%$ of preschool children categorized as having high independence level, $67.78 \%$ of preschool children categorized as having moderate independence level, and $15.55 \%$ of preschool children categorized as having low independence level. There was positive and significant influence between democratic parenting style toward independence. It was proven by the value of rcalculation of democratic parenting style variable and independence variable which was 0.236 , while rtable was 0.207 . It can be seen that rcalculation was higher than rtable. The amount of contribution of democratic parenting style toward independence was $5.6 \%$, while $94.4 \%$ was determined by other variables or factors which were not discussed in this research. Application/Improvements: A positive influence between democratic parenting style towards the children independence occured. The parents had better to be open-minded, close to be like friend to the children and care to their needs.
\end{abstract}

Keywords: Democratic, Education, Independence, Parenting Style, Preschool Children

\section{Introduction}

Independence is very important in a person's life because with independence children can become more responsible in meeting their needs and foster self-confidence in children. A child who has a sense of independence will be able to adjust to the environment, and the environment of the child itself, and can overcome difficulties that occur. Independence can be interpreted as a free personality form of dependence, not as a person without socialization but as self-directed through environmental influences. The practice of parenting has a significant influence on cognitive development and academic outcomes $\frac{1-5}{}$ and also in early childhood independence. Early life experiences play an important role in child development and can provide the foundation for future health ${ }^{5}$. The idea of human development encourages in the context of the environment in which one lives ${ }^{6}$.

Physical factors in the environment have also been shown to affect child development ${ }^{4,7}$ and early childhood independence. A clean and safe environment for children is essential to ensure a positive development trajectory. Improved levels of health with the physical environment ${ }^{4,8}$. Children living in solid conditions have a higher

${ }^{*}$ Author for correspondence 
risk $^{9}$. Environmental factors that contribute to the health and safety of children are also consistently described in the empirical literature ${ }^{7,10,11}$. Personal hygiene, nutrition, and risks associated with cognitive and psychological development ${ }^{12-14}$. Learning is a mental activity (psychic) that requires placing in interaction with the environment that produces change, the change of knowledge, the understanding of skills, and the value of attitude. Moreover, learning is the business process by individuals to gain new behavioral changes as a result of the individual's own experience in interaction with the environment. The type of parenting can be categorized into three types of authoritative or democratic style of parenting, authoritarian parenting type, patient type, and neglect type ${ }^{15}$. In this research, the type of careful parenting is a democratic parenting style. Democratic parenting style is a parenting pattern that involves and accepts the child completely. Parents of this type encourage their children to learn. However, independently, parents still set limits and supervision of children. A democratic parenting style (authoritative) encourages children to be independent but still sets limits and controls on the actions of children and parents to show their warmth and compassion $\frac{16}{}$.

The characteristics and nature of democratic parenting are that parents view children as individuals who grow and develop and have their own initiative $e^{15}$. Parents give freedom with a sense of responsibility to the child to do activities and hang out with friends. Children from different parenting styles in Bengkulu City have different attitudes regarding to children's independence. This can be seen from the attitude of a very diverse parenting style that can affect the learning process; it shows the ability of children in its development is very diverse. Independent children have good learning skills, but children who are not self-sufficient is also quite good in their learning ability development. Parenting styles are varied between one parent one with another and are inconsistent, so that many children in Bengkulu City have different independent-learning attitudes.

This study is limited to the same parenting styles and limited independence on the independence of children's learning. The formulation of the problem in this research was to know how the application of parenting styles for preschool children in Bengkulu City, how the independence of preschool children in Bengkulu City was, and how the influence of parenting styles on the independence of preschool children in Bengkulu City was. The purposes of this research were to know the parenting style implemented by parents of preschool children, the level of independence of preschool children, and the influence of parenting style of parents toward independence. This research can give contribution or benefit as study material and consideration about the importance of understanding the characteristics of preschool children in learning process in Bengkulu City, to foster self-reliance of children, can be a pattern and strategy in improving teacher performance of early childhood educator as teacher at unit level of professional education in improving the intelligence and mental development of children, as input to the school about the need for school learning program by paying attention to the parenting style in order to foster the attitude of independence in children, as input for parents in educating and nurturing their children.

The emergence of independence does not just happen, one of the factors that affect the independence of children is the parenting pattern applied by parents. In the implementation of democratic parenting, children will be able to develop independence ${ }^{16}$. Democratic parenting style will have an impact on the child. The child of the democratic parent will grow into an independent child, firmly against himself, friendly with peers and willing to cooperate with parents ${ }^{15}$.

The hypothesis is a temporary answer to the research that the truth must still be tested empirically and also the theoretical conclusions derived from the literature review that will provide direction to the data collection used and also give direction to the analysis of data used. Based on the literature review, theoretical studies, the framework of thinking and problems issued, it can be formulated hypothesis as follows "There is a positive and significant influence between parenting style of parents toward the independence of preschool children in Bengkulu City".

\section{Research Methodology}

\subsection{Participant}

The population of this study took the sample size by $25 \%$ of the total number of preschool children that were selected as population. So that the number of preschool children samples are as many as two Sub-districts. Then the two sub-districts are selected randomly. The result was selected two sub-districts namely Nusa Indah with 62 children and Kebun Kenanga with 28 children, so that 
the total samples were 90 children in Ratu Agung District of Bengkulu City.

\subsection{Instrument}

In this study, the instrument used was the test scale. There were two scales used, the first scale was the parenting pattern scale that refers to the description of the influence of "Parenting style" on the behavior of children and based on the two dimensions of parenting style which are demandingness and responsiveness $s^{17}$. The second scale was the scale of Independence in which the emergence of independence does not happen just like that, one of the factors that affect the independence of children is the parenting pattern applied by parents ${ }^{16,17}$. Based on several theories that have been mentioned, the researchers agree with the theory ${ }^{18}$ that the validity criterion is reduced to 0.25 with consideration that the number of items that pass to be sufficient (Table 1).

Table 1. Summary of the result of validity test of parents' parenting style variable and independence variable

\begin{tabular}{|l|l|l|l|l|}
\hline No. & Variable & & Total of Item & \\
\cline { 3 - 5 } & & $\begin{array}{l}\text { Total } \\
\text { Item }\end{array}$ & Valid Item & $\begin{array}{l}\text { Failed } \\
\text { Item }\end{array}$ \\
\hline 1. & Parenting Syle & 47 & 32 & 15 \\
\hline 2. & Independence & 40 & 22 & \\
\hline
\end{tabular}

Reliability is expressed by the reliability coefficients $\frac{18}{18}$ whose numbers are in the range from 0 to 1.00 . The higher the reliability coefficient close to 1.00 , it means the higher the reliability. Conversely the lower coefficient close to the number 0 means the lower the reliability.

The data will also be analyzed with the help of Statistical Package for Social Science program (SPSS version 16.0 for windows) to find out whether or not there is any influence of parenting style and students' emotional intelligence. The process of data analysis assisted SPSS program such as checking item validity and item reliability, and test of normality, linearity and hypothesis.

The sampling technique used was random cluster sampling of Preschool Children of Ratu Agung District of Bengkulu City which was chosen as research location. Research was conducted on Wednesday and Thursday $22^{\text {nd }}-23^{\text {rd }}$ of January 2017 . The following research was a presentation of data descriptions of each variable obtained by researchers in the field.

\section{Results and Discussion}

The instrument used by the researcher to obtain data was by test scale. The first scale prepared by the researcher consisted of 47 items that were used as trial scale. After conducting the trial, there were 15 items that were crossed so that there were only 32 items as shown in Table 2 .

From the 32 Items of the valid and reliable trial test scale then composed to be the scale that was used as research instruments. Table 3 shows the explanation of items based on parenting dimension classification.

The total of respondents who were 90 students. Based on the calculation using Microsoft Excel, the researcher calculated the score of each student for every parenting

Table 2. List of parenting

\begin{tabular}{|l|l|l|}
\hline Item & Number of Items & Number of Items \\
\hline Crossed Items & $2,5,14,16,17,20,21,26,32,34,36,38,41,46,47$ & 15 \\
\hline $\begin{array}{l}\text { Valid and reliable Items } \\
\text { used in this research }\end{array}$ & $1,3,4,6,7,8,9,10,11,12,13,15,18,19,22,23,24$, & 32 \\
\hline
\end{tabular}

Table 3. Item explanation based on parenting dimension

\begin{tabular}{|l|l|l|l|l|}
\hline Dimension & Item Number & Item Total & Maximum Score & Minimum Score \\
\hline Responsiveness & $\begin{array}{l}2,3,4,6,9,10,12, \\
14,15,16,17,20, \\
\end{array}$ & 18 & $4 \times 18=72$ & $1 \times 18=18$ \\
\hline Demandingness & $\begin{array}{l}1,5,7,8,11,13,18, \\
19,22,26,27,\end{array}$ & 14 & & \\
& 28,29, and 32 & & & \\
\hline Item Total & & 32 & & \\
\hline
\end{tabular}


Table 4. List of independence items

\begin{tabular}{|l|l|l|}
\hline Items & Items Number & Items' Total \\
\hline Dropped Items & $\begin{array}{l}1,2,4,5,7,10,14,15,16,17,18,19,20,21, \\
23,32,34, \text { and 38 }\end{array}$ & 18 \\
\hline $\begin{array}{l}\text { Valid and Reliable Items used in } \\
\text { this research }\end{array}$ & $\begin{array}{l}3,6,8,9,11,12,13,22,24,25,26,27,28, \\
29,30,31,33,35,36,37,39, \text { and 40 }\end{array}$ & 22 \\
\hline
\end{tabular}

dimension and transform it into a percentage to ensure the wight of every parenting dimension similar. The score of responsiveness and demandingness dimension were compared. If the score of responsiveness dimension was bigger than the demandingness, the applied parenting was permissive parenting, if the score of responsiveness dimension was smaller than the demandingness, the applied parenting was democratic, if both of them were similar, the applied parenting was democratic. After conducting the calculation, the data about parenting style which was commonly used by the parents of preschool students in Ratu Agung District was democratic. This was obtained as the score of responsiveness and demandingness dimension were both high or have the percentage more than $50 \%$. Therefore, it can be concluded that parenting style that was applied by the parents of preschool students on Ratu Agung District was democratic parenting style.

The earlier scale composed by the researcher consisted of 40 items used as trial scale. After conducting the trial, there were 18 items dropped therefore the items left were 22 items, as shown in Table 4.

The 22 trial scale items which were valid and reliable were constructed to be the scale that was used as the research instrument. The ideal maximum score of independence were $22 \times 4=88$ and the ideal minimum score was $22 \times 1=22$. Based on the calculation using SPSS 16.0 for Windows.

The research result regarding the independence led to data is shown in Table 5.

In order to decide the weight of emotional category intelligent, therefore the researcher used these following formulas:

$$
\begin{aligned}
& X \geq \mu+1 . \sigma \\
& \mu-1 \cdot \sigma \leq X<\mu+1 \cdot \sigma \quad \text { Category of High } \\
& \text { Category of }
\end{aligned}
$$

Moderate

$$
\mu-1 . \sigma<\mathrm{X} \quad \text { Category of Low }
$$

Notes:

$\mathrm{X}=$ Score $\mu=$ mean $\sigma=$ standard of deviation. Based on the data above, independence category was obtained as shown in Table 6 .
Table 5. Independence data

\begin{tabular}{|l|l|}
\hline Valid (N) & 90 \\
\hline Missing & 0 \\
\hline Mean & 68.6000 \\
\hline Median & 68.5000 \\
\hline Std. Deviation & 6.46825 \\
\hline Minimum & 46.00 \\
\hline Maximum & 85.00 \\
\hline
\end{tabular}

Table 6. Category of independence

\begin{tabular}{|l|l|l|l|}
\hline Interval & Frequency & Percentage (\%) & Category \\
\hline $\mathrm{X} \geq 75,07$ & 15 Children & 16,67 & High \\
\hline $\begin{array}{l}62,13 \leq \mathrm{X}< \\
75,07\end{array}$ & 61 Children & 67,78 & Moderate \\
\hline $\mathrm{X}<62,13$ & 14 Children & 15,55 & Low \\
\hline Total & 90 Children & $100 \%$ & \\
\hline
\end{tabular}

Based on the research result, it was known that the independence level of preschool children in the District of Ratu Agung Bengkulu City in which the preschool children who had high independence score were 15 children or $16,67 \%$, the children who had moderate independence score were 61 children or $67,78 \%$, the children who had low independence score were 14 children or $15,55 \%$. Thus, generally, most of the preschool children in the District of Ratu Agung Bengkulu city has moderate independence. For further information, it can be seen from the histogram in Figure 1.

The normality test was used by One-Simple Kolmogorov Smirnov. The result of normality test could confirm that all data were normally distributed with significance value 0.475 for the independent variable and 0.597 for the parenting style variable. The minimum requirement for normal distribution had been acquired where the significance value must be bigger than 0.05 . Linear test also used ANOVA Table. The result of linear 
test indicated that parenting style had linear relation with the children's independence. It was proven by the linear significance value of 0.016 for the parenting style and 0.017 for the children's independence. A condition that must present with a linear data is that the linear significance value must be lower than 0.05 .

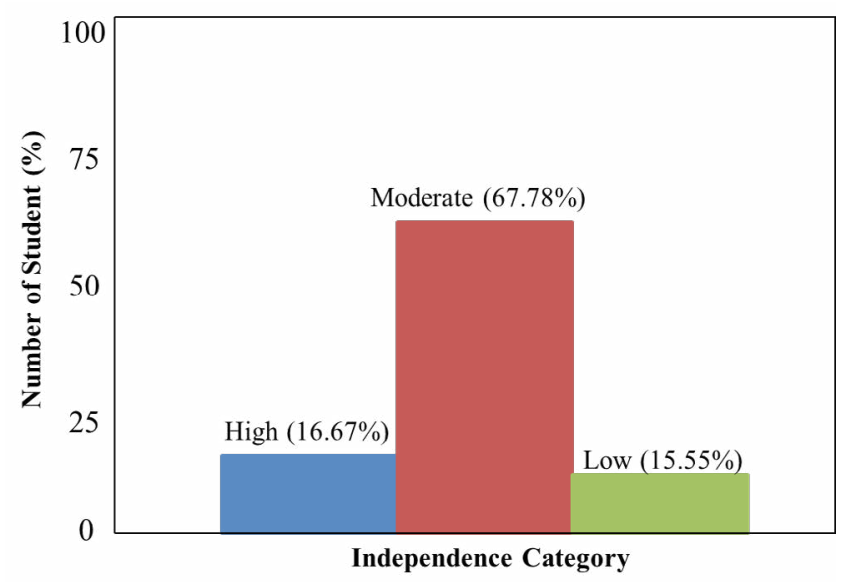

Figure 1. Histogram of independence category of preschool children.

The hypothesis test using simple regression analysis ${ }^{19}$ technique with the regression value result were the $r_{\text {value }}$ parenting style and independence variable which were $0.236 . \mathrm{r}_{\text {value }}$ was positive. $\mathrm{R}_{\text {table }}$ with the $\mathrm{N}=90$ and the element of error $5 \%$ which was 0.207 . In conclusion it was proven that $r_{\text {value }}$ was bigger than $r_{\text {table }}(0.236>0.207)$ and can be concluded that there was a strong relation between democratic parenting style variable and independence. Determination index $\left(\mathrm{r}^{2}\right)$ could be seen from th $\mathrm{R}$ square of regression analysis table. The value of $\mathrm{R}$ square was 0.055 . Thus, the influence of parenting style $(\mathrm{X})$ towards independence $(\mathrm{Y})$ was $0.055 \times 100 \%=5.4 \%$, while $94.4 \%$ was determined by varibale or other factors which were not discussed in this research. According the Hypothesis test above, $\mathrm{H}_{0}$ was rejected and $\mathrm{H}_{\mathrm{a}}$ was accepted. Hence, it can be concluded that there was a significance and positive influence between the parenting style towards the independence of preschool children.

Based on the research result, the preschool children who had high independence category were 15 children. The preschool children who had independence which were categorized as moderate criteria consisted of 61 children. On the other side, the total of preschool children who had low independence score were only 14 children. This result is in line with the interview result that was conducted in Ratu Agung district Bengkulu City at the moment before the research had been started. The interview was conducted through one of class teachers whose class were chosen the be the interview source. The result of the research showed that most of the preschool children parents in Ratu Agung District Bengkulu City implemented democratic parenting style. The result of the research proved that the parenting style, especially democratic parenting style gave positive and significant contribution towards the independence of preschool children. The high value of correlation coefficient between the parenting style and independence was 0.236. Even though the correlation value of parenting style and the independence of preschool children was law, this still showed the improvement of parenting style that was implemented, therefore the better the independence of preschool children was. The determination index $\left(\mathrm{R}^{2}\right)$ of this research was 0.056 . In conclusion, the contribution of parenting style $(\mathrm{X})$ towards the independence $(\mathrm{Y})$ was $0.056 \times 100 \%=5.6 \%$. Meanwhile the $94.4 \%$ was determined by variable or other factors that were not discussed in this research.

\section{Conclusion}

From the research result and discussion that was obtained about the parenting style influence towards the independence, it can be concluded that:

a. Most of the parents of preschool children, District of Ratu Agung Bengkulu City implemented democratic parenting style that gave demandingness and responses properly to the children.

b. The average of independence level of preschool children in the District of Ratu Agung was categorized moderate.

c. There was a positive and significant influence between democratic parenting style towards the children independence.

From the research result regarding the parenting style influence towards the independence of preschool children in Ratu Agung District, the researcher proposed a recommendation which the parents had better to be open-minded in socialization, close to be like friend to the children and care to their needs, problems so that they will feel given attention and appreciated and comfortable. The parents are supposed to listen the children's problem from 
the perspective of them. The teachers are also expected to give a more intensive guide and role model of independence in problem-solving according to the children ability, in the process of learning personal independence so that their whole potential can be improved and created an independent person. The teachers are expected to cooperatively work with the parents so that the development of the children in home can be continued in the school by being supported by learning activities that are the regular activities for independent learning.

\section{References}

1. Andrade SA, Santos DN, Bastos AC, Pedromônico MR, Almeida-Filho ND, Barreto ML. Family environment and child's cognitive development: An epidemiological approach. Revista de Saúde Pública. 2005; 39(4):606-11. https://doi. org/10.1590/S0034-89102005000400014. PMid:16113911

2. Leventhal T, Brooks-Gunn J. The neighborhoods they live in: The effects of neighborhood residence on child and adolescent outcomes. Psychological Bulletin. 2000; 126(2):309-37. https://doi.org/10.1037/00332909.126.2.309. PMid:10748645

3. Pendergast LL, Kaplan A. Instructional context and student motivation, learning, and development: Commentary and implications for school psychologists. School Psychology International. 2015; 36(6):638-47. https://doi. org/10.1177/0143034315613560

4. Shaw M. Housing and public health. Annual Review of Public Health. 2004; 25:397-418. https://doi.org/10.1146/ annurev.publhealth.25.101802.123036. PMid:15015927

5. Shonkoff JP, Garner AS, Siegel BS, Dobbins MI., Earls MF, Garner AS, Wood DL. The lifelong effects of early childhood adversity and toxic stress. Pediatrics. 2012; 129(1):e232-46. https://doi.org/10.1542/peds.2011-2663. PMid:22201156

6. Bronfenbrenner, U. Toward an experimental ecology of human development. American Psychologist. 1977; 32(7):513-31. https://doi.org/10.1037/0003-066X.32.7.513

7. Ferguson KT, Cassells RC, MacAllister JW, Evans GW. The physical environment and child development: An international review. International Journal of Psychology. 2013; 48(4):437-68. https://doi.org/10.1080/00207594.2013.8041 90. PMid:23808797 PMCid:PMC4489931
8. Bailie RS, Stevens MR, McDonald E, Halpin S, Brewster D, Robinson G, Guthridge S. Skin infection, housing and social circumstances in children living in remote indigenous communities: Testing conceptual and methodological approaches. BMC Public Health. 2005; 5:128-40. https://doi.org/10.1186/14712458-5-128. PMid:16336656 PMCid:PMC1334180

9. Delgado J, Ramirez-Cardich ME, Gilman RH, Lavarello R, Dahodwala N, Bazan A, Rodríguez V, Cama RI, Tovar M, Lescano A. Risk factors for burns in children: crowding, poverty, and poor maternal education. Injury Prevention. 2002; 8(1):38-41. https://doi.org/10.1136/ip.8.1.38. PMid:11928972 PMCid:PMC1730827

10. Grandjean P, Landrigan PJ. Developmental neurotoxicity of industrial chemicals. The Lancet. 2006; 368:2167-78. https://doi.org/10.1016/S0140-6736(06)69665-7

11. Lanphear BP, Hornung R, Khoury J, Yolton K, Baghurst P, Bellinger DC, Roberts R. Low-level environmental lead exposure and children's intellectual function: An international pooled analysis. Environmental Health Perspectives. 2005; 113(7):894-9. https://doi.org/10.1289/ehp.7688. PMid:16002379 PMCid:PMC1257652

12. Aiello AE, Larson EL. What is the evidence for a causal link between hygiene and infections? Lancet Infectious Diseases. 2002; 2(2):103-10. https://doi.org/10.1016/ S1473-3099(02)00184-6

13. Choi GY, Park SS. An analysis of actual conditions with the infectious disease of Middle East Respiratory Syndrome Coronavirus (MERS-CoV) spreading in South Korea. Indian Journal of Science and Technology. 2016; 9(25):1-7. https://doi.org/10.17485/ijst/2016/v9i25/97228

14. Walker SP, Wachs TD, Gardner JM, Lozoff B, Wasserman GA, Pollitt E, Carter JA. Child development: Risk factors for adverse outcomes in developing countries. The Lancet. 2007; 369(9556):145-57. https://doi.org/10.1016/S01406736(07)60076-2

15. Hasan M. Pendidikan anak usia dini. DIVA press: Yogyakarta; 2009. p. 1-372.

16. Santrock JW. Life - Span development: Perkembangan Masa Hidup. Erlangga: Jakarta; 2002.

17. Yusuf S. Psikologi Perkembangan Anak Dan Remaja. PT Remaja Rosdakaryam; 2011.

18. Azwar S. Reabilitas dan Validitas. Pustaka Pelajar: Yogyakarta; 2010.

19. Sugiyono. Metode Penelitian Kuantitatif, Kualitatif dan Kombinasi. Bandung: Alfabeta; 2012. 